Ovarian activity in Fleckvieh, Brown Swiss and two strains of Holstein-Friesian cows in pasture-based, seasonal calving dairy systems

Piccand, V ; Meier, S ; Cutullic, E ; Weilenmann, S ; Thomet, P ; Schori, F ; Burke, C R ; Weiss, D ; Roche, J R ; Kunz, P L

Abstract: The objectives of the study were to compare the ovarian activity of Holstein-Friesian (CH HF), Fleckvieh (CH FV) and Brown Swiss (CH BS) dairy cows of Swiss origin with that of Holstein-Friesian (NZ $\mathrm{HF}$ ) dairy cows of New Zealand origin, the latter being used as a reference for reproductive performance in pasture-based seasonal calving systems. Fifty, second-lactation NZ HF cows were each paired with a second-lactation Swiss cow (17, 15 and 18 CH HF, CH FV and CH BS respectively) in 13 pasture-based, seasonal-calving commercial dairy farms in Switzerland. Ovarian activity was monitored by progesterone profiling from calving to first breeding service. CH BS cows produced less energy-corrected milk (mean $22 \cdot 8 \mathrm{~kg} / \mathrm{d})$ than the other breeds $(26 \cdot 0-26 \cdot 5 \mathrm{~kg} / \mathrm{d})$ during the first $100 \mathrm{~d}$ of lactation. CH HF cows had the lowest body condition score (BCS) at calving and the greatest BCS loss from calving to $30 \mathrm{~d}$ post partum. Commencement of luteal activity (CLA) was later for NZ HF than for $\mathrm{CH} \mathrm{FV}(51 \cdot 5 \mathrm{v}$. $29 \cdot 2 \mathrm{~d} ; \mathrm{P}<0 \cdot 01)$, with $\mathrm{CH} \mathrm{HF}$ and $\mathrm{CH}$ BS intermediate $(43 \mathrm{~d})$. On average, $\mathrm{NZ} \mathrm{HF}$ and $\mathrm{CH}$ HF cows had one oestrous cycle before the onset of the seasonal breeding period; this was less $(\mathrm{P}<0 \cdot 01)$ than either $\mathrm{CH} \mathrm{FV}(1 \cdot 7)$ or $\mathrm{CH}$ BS $(1 \cdot 6)$. There was a low prevalence of luteal persistency $(3 \%)$ among the studied cows. First and second oestrous cycle inter-ovulatory intervals did not differ between breeds $(20 \cdot 5-22 \cdot 6 \mathrm{~d})$. The luteal phase length of CH BS during the second cycle was shorter $(10 \cdot 6 \mathrm{~d})$ than that of the other breeds $(13 \cdot 8-16 \cdot 0 \mathrm{~d})$, but the inter-luteal interval was longer $(9 \cdot 8 \mathrm{~d} \mathrm{v} \cdot 7 \cdot 0-8 \cdot 0 \mathrm{~d})$. The results suggest that the Swiss breeds investigated have a shorter interval from calving to CLA than NZ HF cows.

DOI: https://doi.org/10.1017/S0022029911000586

Posted at the Zurich Open Repository and Archive, University of Zurich

ZORA URL: https://doi.org/10.5167/uzh-60066

Journal Article

Published Version

Originally published at:

Piccand, V; Meier, S; Cutullic, E; Weilenmann, S; Thomet, P; Schori, F; Burke, C R; Weiss, D; Roche, J R; Kunz, P L (2011). Ovarian activity in Fleckvieh, Brown Swiss and two strains of Holstein-Friesian cows in pasture-based, seasonal calving dairy systems. Journal of Dairy Research, 78(4):464-470.

DOI: https://doi.org/10.1017/S0022029911000586 


\title{
Ovarian activity in Fleckvieh, Brown Swiss and two strains of Holstein-Friesian cows in pasture-based, seasonal calving dairy systems
}

\author{
Valérie Piccand ${ }^{1}$, Susanne Meier ${ }^{2}$, Erwan Cutullic ${ }^{1}$, Sara Weilenmann ${ }^{3}$, Peter Thomet ${ }^{1}$, Fredy Schori $^{4}$, \\ Chris R Burke ${ }^{2}$, Daniel Weiss ${ }^{5}$, John R Roche ${ }^{2}$ and Peter L Kunz ${ }^{1}$ \\ ${ }^{1}$ Swiss College of Agriculture, 3052 Zollikofen, Switzerland \\ ${ }^{2}$ DairyNZ Limited, Private Bag 3221, Hamilton 3240, New Zealand \\ ${ }^{3}$ Vetsuisse Faculty, University of Zürich, 8052 Zürich, Switzerland \\ ${ }^{4}$ Agroscope Liebefeld-Posieux Research Station ALP, 1725 Posieux, Switzerland \\ ${ }^{5}$ TU ARGE Landnutzung, Mühlenweg 12a, 85354 Freising, Germany
}

Received 2 March 2011; accepted for publication 13 July 2011; first published online 16 August 2011

\begin{abstract}
The objectives of the study were to compare the ovarian activity of Holstein-Friesian (CH HF), Fleckvieh (CH FV) and Brown Swiss (CH BS) dairy cows of Swiss origin with that of Holstein-Friesian (NZ HF) dairy cows of New Zealand origin, the latter being used as a reference for reproductive performance in pasture-based seasonal calving systems. Fifty, second-lactation NZ HF cows were each paired with a second-lactation Swiss cow $(17,15$ and $18 \mathrm{CH} \mathrm{HF}, \mathrm{CH}$ FV and CH BS respectively) in 13 pasture-based, seasonal-calving commercial dairy farms in Switzerland. Ovarian activity was monitored by progesterone profiling from calving to first breeding service. $\mathrm{CH}$ BS cows produced less energy-corrected milk (mean $22 \cdot 8 \mathrm{~kg} / \mathrm{d}$ ) than the other breeds $(26 \cdot 0-26 \cdot 5 \mathrm{~kg} / \mathrm{d}$ ) during the first $100 \mathrm{~d}$ of lactation. $\mathrm{CH}$ HF cows had the lowest body condition score (BCS) at calving and the greatest BCS loss from calving to $30 \mathrm{~d}$ post partum. Commencement of luteal activity (CLA) was later for NZ HF than for CH FV ( $51 \cdot 5$ v. $29 \cdot 2 \mathrm{~d} ; P<0 \cdot 01)$, with CH HF and CH BS intermediate (43 d). On average, NZ $\mathrm{HF}$ and $\mathrm{CH} \mathrm{HF}$ cows had one oestrous cycle before the onset of the seasonal breeding period; this was less $(P<0 \cdot 01)$ than either CH FV (1 -7) or CH BS (1.6). There was a low prevalence of luteal persistency $(3 \%)$ among the studied cows. First and second oestrous cycle inter-ovulatory intervals did not differ between breeds (20.5-22.6 d). The luteal phase length of $\mathrm{CH}$ BS during the second cycle was shorter $(10 \cdot 6 \mathrm{~d})$ than that of the other breeds $(13 \cdot 8-16 \cdot 0 \mathrm{~d})$, but the inter-luteal interval was longer $(9 \cdot 8 \mathrm{~d}$ v. $7 \cdot 0-8 \cdot 0 \mathrm{~d}$ ). The results suggest that the Swiss breeds investigated have a shorter interval from calving to CLA than NZ HF cows.
\end{abstract}

Keywords: Genetic strain, fertility, progesterone.

Pasture-based seasonal-calving dairy production systems have been introduced into Switzerland $(\mathrm{CH})$ in the past 10 years to reduce production costs (Blättler et al. 2004). These systems require that herd feed demand matches pasture growth (Holmes et al. 2007) which is achieved by having discrete periods of breeding and calving lasting 1014 weeks on an annual cycle. At the cow level, each step of the reproductive process is crucial (ovarian activity, oestrus, insemination and the establishment of pregnancy)

*For correspondence; e-mail: valerie.piccand@bfh.ch and the choice of an adapted breed or strain is a key of the system.

Many studies of Holstein-Friesian (HF) cows from differing geographical origins and breeding objectives report that a high proportion of North American (NA) genetic background is linked with poorer reproductive performance (Horan et al. 2005; Fulkerson et al. 2008; Macdonald et al. 2008), compromising their suitability for compact calving systems. Some of this poorer performance has been linked to ovarian dysfunction, in particular, a high proportion of persistent corpus luteum (Royal et al. 2002; Petersson et al. 2006).

Although Swiss dairy cows have been highly influenced by NA genetics, as local dual-purpose breeds were crossed 
with NA Red Holstein, Brown Swiss or HF breeds from the late 1960s (Flückiger, 1990; Wegmann et al. 1999; Hagger, 2005), functional traits have also been an important component of Swiss genetic selection programmes for more than three decades (Böbner, 1994).

A 3-year experiment (2007-2009) was thus designed to examine the suitability of the three predominant Swiss dairy breeds, Swiss Holstein-Friesian (CH HF), Swiss Fleckvieh $(\mathrm{CH}$ FV) and Swiss Brown Swiss (CH BS) for seasonalcalving, pasture-based Swiss milk production systems, by comparing them with New Zealand (NZ) Holstein-Friesian (NZ HF) cows; the latter being chosen as a reference population, recognized for their ability to achieve good fertility in such systems (Kolver et al. 2002; Horan et al. 2005; Macdonald et al. 2008). Reproductive performance differed among breeds (Piccand et al. 2011) with CH FV cows achieving the best reproductive performance: high submission and conception rates led to high pregnancy rates early in the breeding period. Although NZ HF cows achieved a similar pregnancy rate at the end of the breeding period, only $32 \%$ were pregnant within 3 weeks owing to a low submission rate. Overall, $\mathrm{CH}$ HF cows had lower reproductive performance and $\mathrm{CH}$ BS were intermediate. Overall, these results suggested possible differences in the underlying ovarian activity.

In the present study, we focused on the second year of this experiment to investigate to what extent these differences in reproductive performance among breeds were associated with differences in their ovarian activity. Accordingly, ovarian activity and ovulatory cycle patterns were compared between $\mathrm{CH}$ HF, CH FV, CH BS and NZ HF cows through progesterone profile analysis.

\section{Materials and Methods}

\section{Experimental design}

Fifty NZ HF animals were sourced as pregnant heifers from Ireland, imported into Switzerland in late 2006, and randomly allocated in January 2007 to the commercial farms involved in the project. On every farm, each NZ HF cow was paired with a Swiss breed cow, ensuring the pair was balanced for calving date and age. All trial cows were managed similarly within herd, with the farmer in charge of all management decisions concerning his herd.

The observations reported here were undertaken on 13 selected farms from January to July 2008 and involved the 100 second-lactation cows $(50,17,15,18$ cows of NZ HF, $\mathrm{CH} \mathrm{HF}, \mathrm{CH}$ FV, CH BS, respectively, on 13, 3, 5 and 7 farms, respectively).

\section{Animals}

NZ HF. The $50 \mathrm{NZ}$ HF cows were of NZ genetic origin, a strain of HF selected within seasonal calving pasture-based dairy systems for high milk-component production, fertility, and longevity. These animals had at least two generations of NZ ancestry, represented 11 NZ HF sires (86\% from five sires) and had an average pedigree index Breeding Worth of $N Z \$ 88 \pm 14$. They were, therefore, representative of the 2005-born HF in New Zealand (NZ\$87 \pm 42 ; October 2009, R Wood, NZ Animal Evaluation Limited, Hamilton, New Zealand, personal communication).

$\mathrm{CH}$ HF. The $17 \mathrm{CH} \mathrm{HF}$ cows were from a HF strain of NA origin, but selected within a breeding index that included both milk production and functional traits. These animals represented $13 \mathrm{CH}$ HF sires. Their average pedigree index for milk production (IPQ) was $103 \pm 7 \cdot 7$. They were, therefore, representative of the 2005-born HF in Switzerland (104 $\pm 9 \cdot 3$ IPQ; November 2009, E Barras, Holstein Association of Switzerland, Posieux, Switzerland, personal communication).

CH FV. The $15 \mathrm{CH}$ FV were crosses between Simmental and Red Holstein breeds, with an average of $67 \pm 12 \%$ Red Holstein genetics. The herd society's breeding objectives include milk production, functional traits, and beef characteristics. These animals represented $13 \mathrm{CH}$ FV sires. Their pedigree index for milk production (ILM) was 106 5.4. They were, therefore, representative of the $\mathrm{CH}$ FV living population (101 $\pm 9 \cdot 8$ ILM; November 2009, A Bigler, Swissherdbook, Zollikofen, Switzerland, personal communication).

$\mathrm{CH}$ BS. The $18 \mathrm{CH}$ BS were Brown Swiss cows, mainly of NA origin with only $6 \pm 5 \%$ of Original Brown Swiss genetics. They were selected using a balanced breeding index, including milk production and functional traits. These animals represented $15 \mathrm{CH}$ BS sires. Their average pedigree index for milk production (MIW) was 104 $\pm 5 \cdot 4$. They were, therefore, representative of the 2005-born Brown Swiss in Switzerland (104 \pm 7.9 MIW; November 2009, B Bapst, Swiss Brown Cattle Breeders' Federation, Zug, Switzerland, personal communication).

\section{Farms and herd management}

Farms. The 13 dairy farms were located in different geographical regions and altitudes: eight were located on the Swiss Plateau (lowland), four in the Pre-Alps (hill country) and two in the Jura (hill and mountain country), with an altitude ranging from 440 to $1050 \mathrm{~m}$ and a pasture growth period ranging from 230 to $170 \mathrm{~d}$ (Jeanneret \& Vautier, 1977). Management objectives were similar between herds (low-input, pasture-based, spring-calving system).

Feeding. As generally observed in Switzerland, the winter lactating cow ration (from calving to turn out, at $36 \pm 27$ days in milk) always contained a grass sourced forage. It consisted of hay, or hay and grass silage, or grass silage and maize 
silage ( $n=6,6$ and 1 farm, respectively). Concentrate was fed daily at a rate of $3.5 \pm 1 \cdot 8 \mathrm{~kg} \mathrm{DM} / \mathrm{cow}$ to lactating cows during the winter period (mean $303 \pm 131 \mathrm{~kg} / \mathrm{cow}$ per lactation). Winter rations were estimated to contain $6 \cdot 2 \pm 0 \cdot 4 \mathrm{MJ} \mathrm{NE} / \mathrm{kg}$ DM and $15 \pm 2 \cdot 1 \% \mathrm{CP} / \mathrm{kg} \mathrm{DM}$ (one sample/forage type per farm). Cows were managed on pasture from 23 March $2008( \pm 14 \mathrm{~d})$ and progressively reached full grazing after a 2-3 weeks transition period. At grazing, supplementary feed was offered only during periods of pasture deficit. From the time of turning out to pasture until the end of June, pasture was estimated to contain $6 \cdot 2 \pm 0 \cdot 4$ MJ $\mathrm{NE}_{\mathrm{L}} / \mathrm{kg}$ DM and $21 \pm 3 \cdot 3 \% \mathrm{CP} / \mathrm{kg}$ DM (one sample of offered pasture/month per farm). The dry period ration consisted of hay or grass silage of lower quality than the lactating cow ration.

Reproductive events. The average day of the planned start of mating (PSM) was 16 April $2008( \pm 15$ d). Three farms did not follow strict seasonal rules so did not have fixed PSM dates. For the cows on these farms, artificial PSM dates were calculated for each cow by adding a voluntary waiting period (VWP) to the calving date. The VWP was defined for each farm as the shortest observed interval from calving to service (33, 35 and $37 \mathrm{~d})$. All calving dates, artificial insemination (Al) dates, health events and treatments were recorded. For cows not showing oestrus before PSM, the need for treatment was assessed individually by the farm veterinarian. From the 13 farms, seven introduced a bull into the herd $45 \pm 15 \mathrm{~d}$ after PSM (i.e. after two Al cycles).

\section{Animal measurements and variable definitions}

Milk yield, body condition score and live-weight. Milk volume and composition were assessed monthly. Samples were analysed for fat, protein and lactose with an infrared analyser (Foss, Hillerød, Denmark). From these monthly records, 100-d cumulative variables were calculated as follows:

$\sum_{i=0}^{n} \frac{\text { value }_{i}+\text { value }_{i+1}}{2} \times\left(\right.$ days $_{i+1}-$ days $\left._{i}\right)$

where value $_{i}$ and days $s_{i}$ are the value (e.g. milk yield) and days after calving of the $i^{\text {th }}$ sample, respectively, $\mathrm{n}$ is the number of samples $<100$ days after calving, value $_{0}$ is set to value $_{1}$, days $s_{0}$ is set to 0 , and days $s_{n+1}$ is set to 100 . Body condition score (BCS) was assessed monthly on a 1-5 scale in increments of 0.25 (Edmonson et al. 1989) by the same trained operator on all farms. Calving BCS was considered as the maximum of the two one-month-spaced scores that framed calving. Body condition scores at 30 and $100 \mathrm{~d}$ post partum were calculated from individually fitted cubic spline smoothing curves (smooth.spline function: smoothing parameter $=0 \cdot 25, \mathrm{BCS}$ weights $=5,2$ and 1 at calving, before and after $60 \mathrm{~d}$ post partum, respectively; $\mathrm{R}$ Development Core Team, 2009). Cows were weighed on days $38 \pm 19$, $116 \pm 25$ and $281 \pm 28$ post partum, using a mobile weigh platform (Tru-Test, Auckland, New Zealand). Lactation liveweight was averaged over these three values to calculate milk production efficiency (milk yield per metabolic liveweight, i.e. $\left.\mathrm{Lwt}^{\mathrm{0}}{ }^{\cdot 75}\right)$.

Milk progesterone analysis. Milk samples were collected after cluster removal at the morning milking every second day between calving and first mating date. Additional samples were collected at 10, 21 and $28 \mathrm{~d}$ after the first insemination. Samples were quickly frozen and stored for 12 months at $-18^{\circ} \mathrm{C}$ until analysis. Milk sample were defrosted overnight at $5{ }^{\circ} \mathrm{C}$ and then centrifuged for $10 \mathrm{~min}$ at $3000 \mathrm{rpm}$ at $4{ }^{\circ} \mathrm{C}$ just before analysis. Milk progesterone $\left(\mathrm{P}_{4}\right)$ concentration was assayed in skim milk samples by ELISA (Nalge Nunc International, New York, USA) as described by Meyer et al. (1986). Range of detectable concentration was $0 \cdot 2-12 \cdot 5 \mathrm{ng} / \mathrm{ml}$. Intra- and inter-assay coefficients of variation were $23 \%$ and $23 \%, 12 \%$ and $26 \%$, and $15 \%$ and $17 \%$ for skim milk control samples with low, medium and high progesterone concentrations $(1 \cdot 4,2.3$ and $3.0 \mathrm{ng} / \mathrm{ml})$, respectively.

Progesterone profile analysis. Use of $\mathrm{P}_{4}$ to indicate the onset of luteal activity was similar to the method reported by Royal et al. (2000). Cows were defined as being in luteal phase following ovulation if at least two consecutive samples had milk $\mathrm{P}_{4}$ concentrations greater than $0 \cdot 8 \mathrm{ng} / \mathrm{ml}$ ('positive' sample; Weiss et al, 2004). Commencement of luteal activity (CLA) was the calculated interval from calving to the first positive sample of the first luteal phase, minus $1 \mathrm{~d}$ (sampling bias correction). Inter-ovulatory interval (IOI) was the interval between the first positive samples of two consecutive luteal phases. Luteal phase length (LPL) was the interval from the first to the last positive sample of a luteal phase plus $2 \mathrm{~d}$. Inter-luteal interval (ILI) was the interval between the last and the first positive samples of two consecutive luteal phases minus $2 \mathrm{~d}$. A transient progesterone rise (TPR) corresponds to a single positive sample; TPRs were recorded as they may, in some cases, have been part of a short luteal phase, which was not detected by the sampling routine. Progesterone profiles were classified as Normal, Persistent Corpus Luteum (PCL, if at least one LPL was $\geqslant 19 \mathrm{~d}$ ), Delayed Ovulation of type I (DOV-I, if CLA $\geqslant 45 \mathrm{~d}$ ) or Delayed Ovulation of type II (DOV-II, at least one ILI was $\geqslant 12 \mathrm{~d}$ ). The number of cycles by PSM corresponded to the number of luteal phases started by PSM.

Traditional reproductive parameters. Conception to first service (FSC) was confirmed by three positive $\mathrm{P}_{4}$ samples after $\mathrm{Al}$ (days 10, 21 and 28 post $\mathrm{Al}$ ) and a corresponding subsequent calving date. In two cases conception was only confirmed by positive $\mathrm{P}_{4}$ samples (one cow was culled before calving and one had a mummified calf). Sampling stopped after first service, so for inseminations without $\mathrm{P}_{4}$ information ( $n=46$ cows), dates of conception were 
Table 1. Postpartum ovarian activity parameters of New Zealand Holstein-Friesian (NZ HF; $n=50)$, Swiss Holstein-Friesian (CH HF; $n=17$ ), Swiss Fleckvieh (CH FV; $n=15)$ and Swiss Brown Swiss (CH BS; $n=18$ ) second-lactation dairy cows managed in seasonal-calving pasturebased dairy systems of Switzerland ( $n$ are given per breed in brackets). SED $\max$ is given for continuous variables only (binomial variables were analysed on logit-scale)

\begin{tabular}{|c|c|c|c|c|c|c|c|}
\hline & $n$ & $\mathrm{NZ} \mathrm{HF}$ & $\mathrm{CH} \mathrm{HF}$ & $\mathrm{CH}$ FV & $\mathrm{CH} \mathrm{BS}$ & $\mathrm{SED}_{\max }$ & $P_{\text {breed }}$ \\
\hline \multicolumn{8}{|l|}{ Profile characteristics } \\
\hline Calving to CLAt interval, $d$ & 100 & $51 \cdot 5^{b} \neq(50)$ & $43 \cdot 0^{\mathrm{ab}}(17)$ & $29 \cdot 2^{\mathrm{a}}(15)$ & $42 \cdot 7^{\mathrm{ab}}(18)$ & $9 \cdot 47$ & $0 \cdot 01$ \\
\hline CLA to $\mathrm{Al}$ interval, $\mathrm{d}$ & 73 & $33 \cdot 3(33)$ & $30 \cdot 9(12)$ & $36 \cdot 7(13)$ & $39 \cdot 2(15)$ & $8 \cdot 19$ & 0.69 \\
\hline Cycles before planned start of mating $(n)$ & 97 & $0.99^{\mathrm{a}}(49)$ & $0 \cdot 98^{\mathrm{ab}}(16)$ & $1 \cdot 71^{\mathrm{c}}(14)$ & $1 \cdot 57^{\mathrm{bc}}(18)$ & $0 \cdot 364$ & $<0 \cdot 01$ \\
\hline \multicolumn{8}{|l|}{ Proportion of anoestrous cows by } \\
\hline day 45 post partum, $\%$ & 100 & $48 \cdot 5(50)$ & $22 \cdot 0(17)$ & $9 \cdot 0(15)$ & $34 \cdot 4(18)$ & - & $0 \cdot 10$ \\
\hline day 70 post partum, $\%$ & 100 & $7 \cdot 7(50)$ & $11 \cdot 1(17)$ & $8 \cdot 2(15)$ & $4 \cdot 6(18)$ & - & 0.93 \\
\hline Transient progesterone rises, $\%$ & 100 & $32 \cdot 0(50)$ & $29 \cdot 4(17)$ & $13 \cdot 3(15)$ & $38.9(18)$ & - & $0 \cdot 52$ \\
\hline \multicolumn{8}{|l|}{$1^{\text {st }}$ cycle } \\
\hline Inter-ovulatory interval, d & 58 & $17 \cdot 0(26)$ & $16 \cdot 8(8)$ & $18 \cdot 5(13)$ & $17 \cdot 5(11)$ & $3 \cdot 33$ & 0.93 \\
\hline Luteal phase length, d & 82 & $9 \cdot 6(38)$ & $10 \cdot 5(16)$ & $10 \cdot 9(15)$ & $8.9(13)$ & $1 \cdot 74$ & $0 \cdot 60$ \\
\hline Inter-luteal interval, d & 58 & $7 \cdot 4(26)$ & $6 \cdot 1(8)$ & $7 \cdot 3(13)$ & $8.9(11)$ & $2 \cdot 40$ & $0 \cdot 66$ \\
\hline Inter-ovulatory interval $\leqslant 15 \mathrm{~d}, \%$ & 58 & $46 \cdot 2(26)$ & $50 \cdot 0(8)$ & $30 \cdot 8(13)$ & $27 \cdot 3(11)$ & - & $0 \cdot 58$ \\
\hline \multicolumn{8}{|l|}{$1^{\text {st }}$ and $2^{\text {nd }}$ cycles with IOI§ of $16-30 d$} \\
\hline Inter-ovulatory interval, d & 63 & $20 \cdot 5(24)$ & $22 \cdot 6(7)$ & $21 \cdot 9(18)$ & $20 \cdot 8(14)$ & $1 \cdot 63$ & $0 \cdot 33$ \\
\hline Luteal phase length, d & 63 & $13 \cdot 8^{\mathrm{b}}(24)$ & $16 \cdot 0^{b}(7)$ & $13 \cdot 8^{\mathrm{b}}(18)$ & $10 \cdot 6^{\mathrm{a}}(14)$ & $1 \cdot 60$ & $<0.01$ \\
\hline Inter-luteal interval, d & 63 & $7 \cdot 0^{\mathrm{b}}(24)$ & $7 \cdot 1^{\mathrm{b}}(7)$ & $8 \cdot 0^{\mathrm{b}}(18)$ & $9 \cdot 8^{\mathrm{a}}(14)$ & $1 \cdot 15$ & $<0.01$ \\
\hline
\end{tabular}

estimated from the mating dates and the subsequent calving date, with consideration of the sire's breed gestation length. When several inseminations were performed within the interval [expected - 10; expected + 14], the last AI event was chosen. For natural mating without a recorded mating date, the date of conception was estimated by subtracting the gestation length for the sire's breed from the subsequent calving date.

\section{Statistical analyses}

The GenStat procedure CENSOR (VSN International Ltd., 2007) was used to obtain an estimate of the interval from calving to first luteal activity for cows with censored data (i.e. for cows that had a minimum value for the interval when the P4 monitoring stopped but no actual data). Breed was included as a fixed effect, farm and pair within farm were included as random effects. Cows treated for anoestrus were removed from progesterone analysis from the day of the treatment.

Continuous variables were analysed by linear mixed models including breed as a fixed effect and farm and pair within farm as random effects. Binomial variables were analysed by mixed logistic regressions including breed as a fixed effect and farm as a random effect. Results are expressed as predicted probabilities for each breed. These analyses were performed using $\mathrm{R}$ statistical software (Imer and glmer functions, respectively; Bates \& Maechler, 2010; R Development Core Team, 2009).

\section{Results}

\section{Progesterone-related parameters and reproductive performance}

The timing of CLA differed between breeds (Table 1): CH FV cows had an earlier CLA than NZ HF cows, with $\mathrm{CH}$ HF and $\mathrm{CH}$ BS cows intermediate. This earlier resumption in $\mathrm{CH}$ FV cows was explained by a very compact resumption in comparison with NZ HF cows, as shown in Fig. 1. Profiles were classified as PCL and DOV-II from only 3 and 6 cows, respectively, whereas 42 cows had CLA $\geqslant 45 d$ (DOV-I). There was a tendency for more NZ HF cows to be anoestrous at $45 \mathrm{~d}$ post partum (DOV-I) than $\mathrm{CH} \mathrm{HF}(P<0 \cdot 1)$ and $\mathrm{CH}$ FV $(P<0.06)$ cows. As a result, NZ HF cows completed fewer oestrous cycles before PSM than CH FV cows (Table 1).

First cycle characteristics did not differ between breeds. When first and second cycles were pooled and IOI ranging from 16 to $30 \mathrm{~d}$ were considered (i.e. excluding short first cycles and extreme values), $\mathrm{CH}$ BS had both shorter LPL and longer ILI than other breeds (Table 1). Traditional reproduction parameters are given in Table 2, rather as illustrative key figures than as statistically compared figures, owing to the low number of animals.

\section{Milk yield and BCS}

$\mathrm{CH}$ BS cows produced less energy-corrected milk (ECM) and milk fat and protein than other breeds during early lactation (Table 3). When accounting for $\mathrm{Lwt}^{0.75}$, a dairy efficiency gradient from the least to the most efficient was observed 


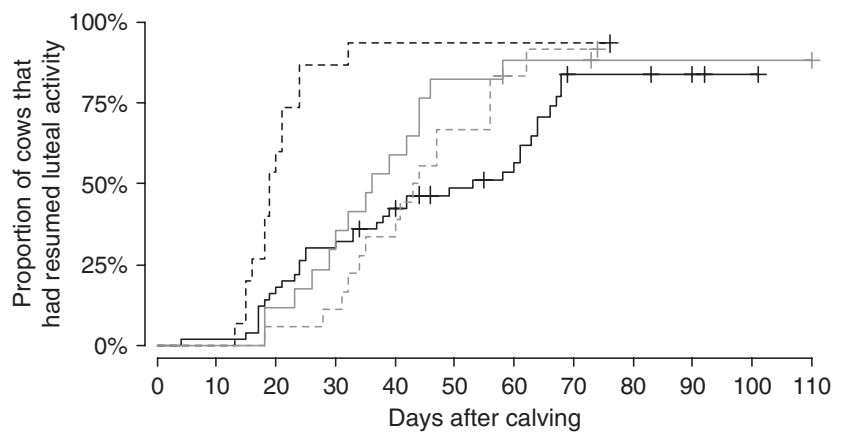

Fig. 1. Proportions of New Zealand Holstein-Friesian (NZ HF; $n=50$; solid black line), Swiss Holstein-Friesian (CH HF; $n=17$; dashed grey line), Swiss Fleckvieh ( $\mathrm{CH} \mathrm{FV} ; n=15$; dashed black line) and Swiss Brown Swiss (CH BS; $n=18$; solid grey line) secondlactation dairy cows managed in seasonal-calving pasture-based dairy systems of Switzerland having their luteal activity resumed. This illustrative plot was drawn from Kaplan-Meier estimates of survival curves that do not account for the farm effect (the calving to commencement of luteal activity intervals and the proportions of anoestrous cows adjusted for farm effect are given in Table 1)

from $\mathrm{CH}$ BS to $\mathrm{CH} F \mathrm{~F}, \mathrm{CH}$ HF and NZ HF. CH FV cows had highest BCS at calving and through early lactation (Table 3). Conversely, $\mathrm{CH} \mathrm{HF}$ had the lowest calving BCS and the greatest BCS loss post partum, with loss most pronounced in the first $30 \mathrm{~d}$ (Table 3).

\section{Discussion}

\section{Commencement of luteal activity}

The NZ HF strain took longer to resume ovarian activity after calving than the other breeds. This result is consistent with a previous report that extended anovulatory periods are a major source of reproductive failure in NZ dairy cows (Macmillan, 2002). To our knowledge, NZ HF always have either longer (McNaughton et al. 2003, Macdonald et al. 2008) or similar (Horan et al. 2005, Chagas et al. 2006), but never shorter CLA than NA HF, despite their higher fertility.

The longer interval from calving to CLA in the NZ HF is in agreement with the high positive correlation between CLA and Predicted Transmitting Abilities for fat (Veerkamp et al. 2000; Royal et al. 2002). The NZ HF strain has been selected for high milk solids (fat plus protein) yield for many decades. In comparison, the three Swiss breeds have been mostly selected on milk volume, which has a lower genetic correlation with CLA. Interestingly, the average CLA increased linearly with the production trait weightings in the selection indices of the four breeds: $39 \%, 54 \%, 53 \%$ and $67 \%$ for $\mathrm{CH} \mathrm{FV}, \mathrm{CH}$ BS, $\mathrm{CH}$ HF and $\mathrm{NZ} \mathrm{HF}$, respectively (year 2009; Swiss herdbook, Swiss Brown Cattle Breeders' Federation, Holstein Association of Switzerland, New Zealand Animal Evaluation Unit).

According to a recent review (Cutullic, 2010), an average interval from calving to CLA of $30 \mathrm{~d}$ would be expected for herds of multiparous cows with such milk yields. The reason for the longer interval in the present study is not known. It may be related to nutrition or BCS. Although recent studies reported no effect of post-partum feeding level effect on CLA (Horan et al. 2005; Burke \& Roche, 2007; Cutullic et al. 2011), possible differences in pre-partum feeding level, calving BCS (Burke \& Roche, 2007), or differences in the proportion of structural to non-structural carbohydrates in post-partum diets (Gong et al. 2002; Burke et al. 2010) between the farms on this study and that reported by Cutullic (2010) cannot be excluded.

Both BCS at calving and BCS change in early lactation, indicating the energy balance of the cow, influence timing of CLA (Butler et al. 1981; Roche et al. 2009; Friggens et al. 2010). Although these associations are plausible within breed, they are unlikely to account for the breed differences reported here. For example, based on their BCS profile, NZ HF should resume ovarian activity earlier. Consistent with this, Pollot et al. (2008) could explain differences in timing to CLA by energy deficit differences within strain, but not between strains. This suggests that there are inherent breed influences on the timing of CLA beyond that of BCS, BCS change or energy balance.

\section{Oestrous cycle traits}

Oestrous cycle characteristics of $\mathrm{CH}$ BS differed from the other breeds, with a shorter LP and longer ILI, although IOI was similar. This may be associated with a slower increase in $\mathrm{P}_{4}$ at the start of the luteal phase for $\mathrm{CH}$ BS cows, similar to that previously reported by Yenikoyé et al. (1981) and Meier et al. (2009). Differences in the follicular wave patterns, not measured in the present study, may also underlie the observed cycle differences. The similarity of IOI however suggests that the numbers of follicular waves per cycle were similar across the breeds (Bleach et al. 2004).

Ovarian abnormalities were scarce, apart from delayed resumption of luteal activity post partum. The late resumption of luteal activity in the present study may, in part, have prevented the occurrence of prolonged luteal phases; however it may also be a consequence of different genetic selection priorities within the breeds evaluated. In Sweden, for example, where fertility traits were included in the genetic index in the 1970s, Petersson et al. (2006) reported only 6 and $11 \%$ prolonged luteal phase profiles in Red and White and Holstein breeds respectively.

\section{Overall reproductive performance}

The low number of animals in this study limits the conclusions that can be drawn about overall reproductive performance. However, the numerical trends observed have been confirmed by the 3-year analysis reported by Piccand et al. (2011).

Late resumption of luteal activity probably explained the low 21-d submission rate in the NZ HF. However, because normal ovarian activity with fertile ovulations resumed 
Table 2. Reproduction parameters of New Zealand Holstein-Friesian (NZ HF; $n=50)$, Swiss Holstein-Friesian (CH HF; $n=17)$, Swiss Fleckvieh $(\mathrm{CHFV} ; n=15)$ and Swiss Brown Swiss (CH BS; $n=18)$ second-lactation dairy cows managed in seasonal-calving pasture-based dairy systems of Switzerland ( $n$ are given per breed in brackets). SED $\max$ is given for continuous variables only (binomial variables were analysed on logit-scale)

Calving to PSM $t, d$

21-d submission rate, $\%$

Conception to first service, $\%$

Conception to first and second service, $\%$

Pregnant within 3 weeks of PSM, \%

Pregnant within 6 weeks of PSM, \%

Pregnant within 9 weeks of PSM, \%

Pregnant within 12 weeks of PSM, \%

Cows treated for anoestrus, $\%$

†Planned start of mating

\begin{tabular}{rlll}
\multicolumn{1}{l}{$n$} & NZ HF & CH HF & CH FV \\
100 & $54(50)$ & $55(17)$ & $52(15)$ \\
100 & $59(50)$ & $56(17)$ & $80(15)$ \\
98 & $60(50)$ & $46(15)$ & $44(15)$ \\
98 & $70(50)$ & $59(15)$ & $72(15)$ \\
97 & $35(49)$ & $27(15)$ & $47(15)$ \\
97 & $71(49)$ & $61(15)$ & $56(15)$ \\
97 & $81(49)$ & $64(15)$ & $77(15)$ \\
97 & $88(49)$ & $77(15)$ & $80(15)$ \\
100 & $11(50)$ & $13(17)$ & $12(15)$
\end{tabular}

\begin{tabular}{rll}
\multicolumn{1}{c}{ CH BS } & SED $_{\max }$ & $P_{\text {breed }}$ \\
$56(18)$ & $3 \cdot 29$ & $0 \cdot 71$ \\
$78(18)$ & - & $0 \cdot 38$ \\
$45(18)$ & - & $0 \cdot 56$ \\
$62(18)$ & - & $0 \cdot 84$ \\
$39(18)$ & - & $0 \cdot 76$ \\
$68(18)$ & - & $0 \cdot 80$ \\
$80(18)$ & - & $0 \cdot 68$ \\
$87(18)$ & - & $0 \cdot 72$ \\
$0(18)$ & - & $0 \cdot 18$
\end{tabular}

Table 3. Milk production and body condition of New Zealand Holstein-Friesian (NZ HF; $\mathrm{n}=50$ ), Swiss Holstein-Friesian (CH HF; $n=17$ ), Swiss Fleckvieh (CH FV; $n=15)$ and Swiss Brown Swiss (CH BS; $n=18)$ second-lactation dairy cows managed in seasonal-calving pasture-based dairy systems of Switzerland

\begin{tabular}{|c|c|c|c|c|c|c|}
\hline Item & NZ HF & $\mathrm{CH} \mathrm{HF}$ & $\mathrm{CH} F \mathrm{~V}$ & $\mathrm{CH}$ BS & $\mathrm{SED}_{\max }$ & $P$ breed \\
\hline \multicolumn{6}{|l|}{ Milk production over first $100 \mathrm{~d}$} & $0 \cdot 08$ \\
\hline ECMキ yield, kg/d & $26 \cdot 3^{b}$ & $26 \cdot 5^{b}$ & $26 \cdot 0^{b}$ & $22 \cdot 8^{a}$ & $1 \cdot 31$ & $<0.01$ \\
\hline milk fat, $\mathrm{kg} / \mathrm{d}$ & $1.08^{b}$ & $1.07^{b}$ & $1 \cdot 05^{b}$ & $0 \cdot 89^{a}$ & $0 \cdot 064$ & $<0.01$ \\
\hline milk protein, $\mathrm{kg} / \mathrm{d}$ & $0 \cdot 86^{b}$ & $0 \cdot 86^{b}$ & $0 \cdot 84^{\mathrm{b}}$ & $0.75^{\mathrm{a}}$ & $0 \cdot 040$ & $<0 \cdot 01$ \\
\hline ECM efficiency $\S\left(\mathrm{kg}\right.$ day $\left.^{-1} . \mathrm{kg}^{-0 \cdot 75}\right)$ & $0 \cdot 243^{c}$ & $0 \cdot 225^{b}$ & $0 \cdot 215^{a b}$ & $0 \cdot 197^{\mathrm{a}}$ & $0 \cdot 012$ & $<0.01$ \\
\hline \multicolumn{7}{|l|}{ Body condition score (BCS), (1-5) scale } \\
\hline BCS at calving & $3 \cdot 16^{b}$ & $2 \cdot 95^{\mathrm{a}}$ & $3 \cdot 41^{\mathrm{c}}$ & $3 \cdot 27^{b c}$ & $0 \cdot 134$ & $<0 \cdot 01$ \\
\hline BCS at $30 \mathrm{~d}$ & $2 \cdot 92^{b}$ & $2 \cdot 58^{\mathrm{a}}$ & $3 \cdot 25^{\mathrm{c}}$ & $3.09^{\mathrm{c}}$ & $0 \cdot 121$ & $<0 \cdot 01$ \\
\hline BCS at $100 \mathrm{~d}$ & $2 \cdot 78^{b}$ & $2 \cdot 35^{a}$ & $3 \cdot 13^{c}$ & $2 \cdot 86^{b}$ & $0 \cdot 123$ & $<0.01$ \\
\hline BCS change from calving to $30 \mathrm{~d}$ & $-0 \cdot 26^{b}$ & $-0 \cdot 42^{a}$ & $-0 \cdot 16^{b}$ & $-0 \cdot 16^{b}$ & $0 \cdot 090$ & $0 \cdot 02$ \\
\hline BCS change from calving to $100 \mathrm{~d}$ & $-0 \cdot 38^{b}$ & $-0 \cdot 60^{a}$ & $-0.28^{b c}$ & $-0 \cdot 40^{a b}$ & $0 \cdot 128$ & $0 \cdot 07$ \\
\hline
\end{tabular}

quickly beyond CLA, they achieved normal 6-week and 12-week pregnancy rates. According to McNaughton et al. (2007), only resumption of luteal activity after $70 \mathrm{~d}$ post partum affects the interval from PSM to conception. This is in agreement with the high final pregancy rates observed in $\mathrm{CH}$ BS and NZ HF cows, although respectively one-third and one-half of these cows were 'delayed' classified $(C L A \geqslant 45 d)$; indeed, most of the cows had resumed luteal activity by day 70 post partum (94 and $90 \%$ respectively). In $\mathrm{CH}$ HF cows, numerically lower pregnancy rates achieved through the breeding season seemed mostly due to poor fertility to insemination or to low oestrus expression, rather than to abnormal ovarian activity, in agreement with many experiments comparing NZ HF strains with high productivity NA strains (Verkerk et al. 2000; Horan et al. 2005; Macdonald et al. 2008). In CH FV cows, the early homogenous CLA allowed a high submission rate and a high 3 -week pregnancy rate, which is a non negligible advantage on the long term in compact calving systems. In the 3-year study (Piccand et al. 2011), this group achieved the best overall reproductive performance.

\section{Conclusions}

The Swiss breeds investigated have a shorter interval from calving to CLA than NZ HF cows. However, ovarian activity is only the first step of the reproductive process and the final reproductive performance is also highly modulated by later steps, such as fertility to insemination.

This study was funded by the Swiss Federal Commission for Innovation and Technology, the Swiss College of Agriculture, Swissgenetics and the Swiss Interest Group for Pasture Based Milk (IG Weidemilch). The authors gratefully acknowledge the collaborating farmers and Barbara Dow for statistical advice and analysis. 


\section{References}

Bates D \& Maechler M 2010 Ime4: Linear mixed-effects models using S4 classes http://CRAN.R-project.org/package=Ime4 $\mathrm{R}$ package version 0.999375-35

Blättler T, Durgai B, Kohler S, Kunz P, Leuenberger S, Müller R, Schäublin H, Spring P, Stähli R, Thomet P, Wanner K, Weber A \& Menzi A 2004 [Opti-Milk Project: Objectives and Basic Information.] Agrarforschung 11 80-85

Bleach ECL, Glencross RG \& Knight PG 2004 Association between ovarian follicle development and pregnancy rates in dairy cows undergoing spontaneous oestrous cycles. Reproduction 127 621-629

Böbner C 1994 [Estimation of economic weighting for secondary production trait by Swiss dual purpose cows with the use of dynamic optimisation.] PhD Thesis, ETHZ, Switzerland

Butler WR, Everett R \& Coppock CE 1981 The relationships between energy balance, milk production and ovulation in post-partum Holstein cows. Journal of Animal Science $\mathbf{5 3}$ 742-748

Burke CR, Kay JK, Phyn CVC, Meier S, Lee JM \& Roche JR 2010 Short communication: Effects of dietary nonstructural carbohydrates pre- and postpartum on reproduction of grazing dairy cows. Journal of Dairy Science 93 4292-4296

Burke CR \& Roche JR 2007 Effects of pasture feeding during the periparturient period on postpartum anovulation in grazed dairy cows. Journal of Dairy Science $\mathbf{9 0} 4304-4312$

Chagas LM, Gore P, Sheahan JA, Lee JM, Watkins PW, Aspin PW \& Roche JR 2006 Diet or strain: effects on postpartum anovulatory interval in dairy cows. Proceedings of the New Zealand Society of Animal Production $\mathbf{6 6}$ 339-343

Cutullic E 2010 Competition between lactation and reproduction in the dairy cow PhD Thesis, University Caen Basse-Normandie, France

Cutullic E, Delaby L, Gallard Y \& Disenhaus C 2011 Dairy cows reproductive response to feeding level differs according to the reproductive stage and the breed. Animal 5 731-740

Edmonson AJ, Lean IJ, Weaver LD, Farver T \& Webster G 1989 A body condition scoring chart for Holstein dairy cows. Journal of Dairy Science 72 68-78

Flückiger N 1990100 [100 years of the Swiss Red and White dairy cow Breeding Federation.] In: Fédération suisse d'élevage de la race tachetée rouge, Zollikofen

Friggens NC, Disenhaus C \& Petit HV 2010 Nutritional sub-fertility in the dairy cow: towards improved reproductive management through a better biological understanding. Animal 4 1197-1213

Fulkerson WJ, Davison TM, Garcia SC, Hough G, Goddard ME, Dobos R \& Blockey M 2008 Holstein-Friesian dairy cows under a predominantly grazing system: Interaction between genotype and environment. Journal of Dairy Science 91 826-839

Gong JG, Lee WJ, Garnsworthy PC \& Webb R 2002 Effect of dietary-induced increases in circulating insulin concentrations during the early postpartum period on reproductive function in dairy cows. Reproduction 123 $419-427$

Hagger C 2005 Estimates of genetic diversity in the brown cattle population of Switzerland obtained from pedigree information. Journal of Animal Breeding and Genetics 122 405-413

Holmes CW, Brookes IM, Garrick DJ, Mackenzie DDS, Parkinson TJ \& Wilson GF 2007 Milk Production from Pasture. Principles and Practices. Massey University, Palmerston North, New Zealand

Horan B, Mee JF, O'Connor P, Rath M \& Dillon P 2005 The effect of strain of Holstein-Friesian cow and feeding system on postpartum ovarian function, animal production and conception rate to first service. Theriogenology 63 950-971

Jeanneret F \& Vautier P 1977 [Mapping of the climatic suitability for agriculture in Switzerland.] Geographisches Institut der Universität Bern, Bern, Switzerland

Kolver ES, Roche JR, Veth MJ de, Thorne PL \& Napper AR 2002 Total mixed rations versus pasture diets: Evidence for a genotype $\times$ diet interaction in dairy cow performance. Proceedings of the New Zealand Society of Animal Production 62 246-251

Macdonald KA, Verkerk GA, Thorrold BS, Pryce JE, Penno JW, McNaughton LR, Burton LJ, Lancaster JAS, Williamson JH \& Holmes CW 2008 A comparison of three strains of Holstein-Friesian grazed on pasture and managed under different feed allowances. Journal of Dairy Science 91 1693-1707

Macmillan KL 2002 Advances in bovine theriogenology in New Zealand. 1. Pregnancy, parturition and the postpartum period. New Zealand Veterinary Journal 50 67-73

McNaughton LR, Sanders KM, Pryce JE, Bracefield GE, Harcourt SJ \& Spelman RJ 2007 Phenotypic relationships between the interval from calving to first luteal activity and fertility in a seasonal dairy production system. Animal Reproduction Science 102 98-110

McNaughton LR, Verkerk GA, Parkinson TJ, Macdonald KA \& Holmes CW 2003 Postpartum anoestrous intervals and reproductive performance of three genotypes of Holstein-Friesian dairy cattle managed in a seasonal pasture-based dairy system. Proceedings of the New Zealand Society of Animal Production 63 77-81

Meier S, Roche JR, Kolver ES, Verkerk GA \& Boston RC 2009 Comparing subpopulations of plasma progesterone using cluster analyses. Journal of Dairy Science 92 1460-1468

Meyer HHD, Gueven B \& Karg H 1986 [Enzyme-immuno assay (EIA) on microtitration plate for progesterone determination in skim milk.] Wiener Tierärztliche Monatsschrift 73 86-92

Petersson K, Gustafsson H, Strandberg E \& Berglund B 2006 Atypical progesterone profiles and fertility in Swedish dairy cows. Journal of Dairy Science 89 2529-2538

Piccand V, Cutullic E, Schori F, Weilenmann S \& Thomet P 2011 [Which cow for pasture-based production systems? Production, reproduction and health.] Recherche Agronomique Suisse 2 252-257

Pollott GE \& Coffey MP 2008 The effect of genetic merit and production system on dairy cow fertility, measured using progesterone profiles and on-farm recording. Journal of Dairy Science 91 3649-3660

R Development Core Team 2009 R: A language and environment for statistical computing. R Foundation for Statistical Computing, Vienna, Austria

Roche JR, Friggens NC, Kay JK, Fisher MW, Stafford KJ \& Berry DP 2009 Invited review: Body condition score and its association with dairy cow productivity, health, and welfare. Journal of Dairy Science 92 5769-5801

Royal MD, Darwash AO, Flint AP, Webb R, Woolliams JA \& Lamming GE 2000 Declining fertility in dairy cattle: changes in traditional and endocrine parameters of fertility. Animal Science 70 487-501

Royal MD, Flint APF \& Woolliams JA 2002 Genetic and phenotypic relationships among endocrine and traditional fertility traits and production traits in Holstein-Friesian dairy cows. Journal of Dairy Science 85 958-967

Veerkamp RF, Oldenbroek JK, van der Gaast HJ \& van der Werf JHJ 2000 Genetic correlation between days until start of luteal activity and milk yield, energy balance, and live weights. Journal of Dairy Science $\mathbf{8 3}$ 577-583

Verkerk GA, Morgan SR \& Kolver ES 2000 Comparison of selected reproductive characteristics in Overseas and New Zealand Holstein-Friesian cows grazing pasture or fed a total mixed ration. Proceedings of the New Zealand Society of Animal Production 60270 274

Wegmann S, Chavaz J, Hitz M, Roulin A \& Savary D 1999100 Years in black and white. Holstein Association of Switzerland, Posieux, Switzerland

Weiss D, Reist M \& Bruckmaier RM 2004 The acyclic period postpartum in automatic and conventional milking. Journal of Veterinary Medicine 268-272

Yenikoyé A, Mariana JC, Ley JP, Jolivet E, Terqui M \& Lemon-Resplandy M 1981 [A mathematical model of the cow progesterone pattern application and proof of breed differences.] Reproduction Nutrition Development 21 561-575 